\title{
Effects of Supplemental Vitamin C (Ascorbic Acid) on the Growth and Health of African Catfish Clarias gariepinus
}

\author{
${ }^{1}$ OKHIONKPAMWONYI, ON; *2EDEMA, CU \\ ${ }^{I}$ Department of Biology, School of Sciences, College of Education, P.M.B. 1144, Ekiadolor Benin City, Edo State, Nigeria. \\ e-mail: okhionsn@gmail.com \\ ${ }^{2}$ Department of Animal and Environmental Biology, Faculty of Life Sciences, University of Benin, Benin City, Edo State, Nigeria. \\ *Corresponding Author's e-mail: edemaclark@yahoo.com
}

\begin{abstract}
Four different diets each containing 37.4\% crude protein were formulated from locally available feed materials to contain 0 (control), 23, 46 and $92 \mathrm{mg} / \mathrm{Kg}$ supplemental Ascorbic acid (AA) respectively. Catfish with average weight of $2-6 \mathrm{~g}$ were stocked and fed twice daily to satiation initially with Coppens fish feed for the first 9 weeks, sorted by weight equality into four ponds at different times; and further fed with the experimental diet till the $26^{\text {th }}$ week. Growth performance was tested using data from length and weight measurements of the fish. Weight gain was generally significantly $(\mathrm{P}<0.02)$ higher in groups fed $92 \mathrm{mg} / \mathrm{Kg} \mathrm{AA}$ and $46 \mathrm{mg} / \mathrm{Kg}$ AA than those fed with $0 \mathrm{mg} / \mathrm{Kg}$ Ascorbic acid and $23 \mathrm{mg} / \mathrm{Kg}$ AA, but those fed $0 \mathrm{mg} / \mathrm{Kg}$ AA showed higher mean weight gain $(527.86 \mathrm{~g})$ than those fed $23 \mathrm{mg} / \mathrm{kg}$ AA $(257.74 \mathrm{~g})$. Protein efficiency ratio was higher in the group fed $0 \mathrm{mg} / \mathrm{kg}$ AA than the other groups. Liver AA was significantly higher $(\mathrm{P}<0.05)$ in groups fed $92 \mathrm{mg} / \mathrm{kg}$ AA. The group which received $0 \mathrm{mg} / \mathrm{Kg}$ AA and $23 \mathrm{mg} / \mathrm{Kg}$ AA in their diets manifested deficiency signs such as nodules on neck, skin lesions, head lesions and very visible sutures, but those fed $46 \mathrm{mg} / \mathrm{Kg}$ AA and $92 \mathrm{mg} / \mathrm{Kg}$ AA had a healthy body appearance. Evidence from this study shows that growth or weight gain of catfish is not solely dependent on supplemental vitamin C availability; but low amounts or absence of supplemental vitamin $\mathrm{C}$ bring about poor health. CJASEM

http://dx.doi.org/10.4314/jasem.v21i1.18
\end{abstract}

Key words: Clarias gariepinus, Ascorbic acid, diets, Health.

High stocking densities, poor feeding management, pathogenic microorganisms and other organic loads in an intensive commercial aquaculture system stimulate the occurrence of poor growth and health of fish stock. The African catfish Clarias gariepinus is a very popular and hardy fresh water fish in Nigeria highly demanded by consumers. Vitamin $\mathrm{C}$ is a highly effective antioxidant, and an enzyme cofactor for the biosystem, collagen hydroxylation and synthesis of Carnitine. It also play massive role in bone development (Gbadamosi et al., 2013). Different signs of deficiency symptoms of vitamin C in catfish such as low collagen of connective tissues, skeletal deformity and fragile bone structure tail erosion, poor growth performance, skin erosion, twisting of the vertebra (lordosis) and deaths (Ibiyo et al., 2007); erratic swimming, flashing, skin darkening and reduced growth (Adewolu and Aro, 2009); broken-head diseases (Behera, 2015), haemorrhages along spinal column, inflammation of dorsal skull bone followed by broken - skull and death have been reported in previous studies. The inability of many fish species to synthesize Vitamin C is well documented (Yamamoto et al., 1985). Ascorbic acid must therefore be supplied through feed. Thus, its deficiency may manifest in diversity of clinical symptoms. This study was undertaken to investigate the effects of selected levels of supplemental vitamin $\mathrm{C}$ in locally manufactured fish diet on the growth and health of catfish Clarias gariepinus.

\section{MATERIALS AND METHODS}

Sample Collection, Preparation and Analysis: An erected flow-through well plastered concrete pond $5.49 \mathrm{~m} \times 1.524 \mathrm{~m} \times 1.3725 \mathrm{~m} \quad(0.00084 \mathrm{ha})$ was partitioned into four (4) compartments each measuring about $1.219 \mathrm{~m} \times 1.524 \mathrm{~m} \times 1.3725 \mathrm{~m}$ in dimension, with water supplied from a bore hole source. Each pond was interlinked to allow uniformity of water quality throughout the experimental period. Water quality parameters including $\mathrm{pH}$, temperature, dissolved oxygen and ammonia were maintained at optimum level recommended by Boyd (1990) for all treatments. Catfish (Clarias gariepinus) fingerlings with initial average weight of $2-6 \mathrm{~g}$ were purchased from Eden farm, Benin, identified (Idodo-Umeh, 2003), stocked and cultured for nine (9) weeks to attain weights between $60-150 \mathrm{~g}$, while being fed with $0.2-$ $2.0 \mathrm{~mm}$ coppens fish feed within that period, during which also sorting of fish by weight similarity was routinely carried out to eliminate effects of varying growth rate of individual fish due to genetic factors (Martins et al., 2005; Chatakondi et al., 2010); into the four ponds to have a stock of 140fish per pond. 
From the tenth week, fish in each of the four ponds were given formulated farm-made pelleted diets with varying vitamin $\mathrm{C}$ levels till the $26^{\text {th }}$ week (table 1 ).

Sampling of fish was carried out randomly every two weeks using scoop net. Ten (10) specimens from each pond at every sampling period were examined physically and measurements of weight, head length, head width, total length and standard length were taken using methods adopted by Panase and Mengumphan (2015). Examined specimen was

Model Equations for Calculating Growth Parameters The growth parameters were calculated as follows: immediately returned into the pond to reduce stress. After sampling was carried out fortnightly, feeding rate was adjusted subsequently. Proximate composition of diet (table 3), liver AA (table 3) determination and AA originality test were carried out in Quality Analytical laboratory, Benin, using spectrophotometric and Association of Analytical Chemists (AOAC, 2000) methods. Fish samples were physically inspected carefully for external deficiency signs.

Weight gain $(\mathrm{WG})=\mathrm{W} 1-\mathrm{W} 2$

Feed conversion ratio $(F C R)=\frac{\text { Total weight of faed consumed }(g)}{\text { Total weighr gained }(g)}$

Protein Intake $(P I)=\frac{\text { Food supplied }(g) \text { w crude protein of food }}{100}$

Protein Ef ficiency ratio $(P E R)=\frac{\text { Mean weight gain }(g)}{\text { Man protein intake }(g)}$

Specific Growth Rate, SGR $(\%$ day $)=\frac{m W 2-m W 1 \times 100}{t}$

Length-weight Relationship, LWR, was determined thus: $W=a L^{b}$

(Eq.6)

Where $\mathrm{W}_{1}$ = initial weight and $\mathrm{W}_{2}=$ final weight, $\mathrm{t}=$ time duration of treatment in days, $\mathrm{ln}=$ natural logarithm, $\mathrm{W}=$ weight of fish $(\mathrm{g}), \mathrm{a}=$ regression constant or intercept, $\mathrm{b}=$ regression coefficient or slope, $\mathrm{L}=$ total length of fish $(\mathrm{cm})$.

Statistical Analysis: Data obtained from the trial were subjected to one-way analysis of variance to test for the effect of dietary treatments and set at 5\% $(\mathrm{P}=0.05)$; and multiple comparison test of the means done using LSD, SNK and DMR in SPSS 10.0 package (Ogbeibu, 2005). Growth and nutritional performance calculations used (Equations 1-6) were similar to those adopted by Ibiyo et al. (2007) and Adewolu and Aro (2009). Data from length, weight, and liver AA were subjected to one-way ANOVA to test for significant difference; Duncan and Multiple range tests for comparisons among groups. The length-weight relationships of $C$. gariepinus in each of the four experimental ponds were evaluated using regression and correlation analysis on logarithm transformed data.

\section{RESULTS AND DISCUSSION}

Liver AA concentration of Analyzed fish sample: The liver AA of analyzed fish samples randomly collected from the control and experimental ponds are presented in table 2. Liver Ascorbic acid was generally higher in the group with higher vitamin $\mathrm{C}$ intake (above 39\% liver AA) while those that received $0 \mathrm{mg} / \mathrm{kg}$ AA had low liver AA (less than $23 \%$ liver AA). This indicates that the liver AA concentration of catfish is dependent on the AA intake in their diets.

Proximate composition of Experimental Diets: Proximate compositions of the experimental diets are presented in table 3 . The average crude protein, crude fat, crude fibre, moisture, ash and carbohydrate in the entire treatment diets utilized were $37.4 \%, 2.9 \%$, $6.53 \%, 0.72 \%, 7.07 \%$ and $45.34 \%$ respectively.

Growth Performance and Nutrient Utilization: Growth Performance and Nutrient Utilization of Fish during the study are presented in table 4 . Mortality was lower in groups fed $92 \mathrm{mg} / \mathrm{kg}$ AA and $46 \mathrm{mg} / \mathrm{kg}$ AA, but highest in groups that received $0 \mathrm{mg} / \mathrm{kg}$ AA $(10.77 \%)$. This reflects the potency AA in healthy development of catfish when in sufficient quantity in their diet. 
Table 1: Feed composition (per 100kg) utilized for the treatment duration in each ponds.

\begin{tabular}{lcccc}
\hline Ingredients & Pond 1 & Pond 2 & Pond 3 & Pond 4 \\
\hline Soya Alfcot (soya cake) & 15 & 15 & 15 & 15 \\
G.N.C (G'nut cake) & 15 & 15 & 15 & 15 \\
Fishmeal 65\% & 15 & 15 & 15 & 15 \\
Fishmeal 72\% & 5 & 5 & 5 & 5 \\
Soya full fat & 4 & 4 & 4 & 4 \\
Wheat offal & 20 & 20 & 20 & 20 \\
Maize (yellow) & 15 & 15 & 15 & 15 \\
Baking flour & 5 & 5 & 5 & 5 \\
Bone meal & 0.5 & 0.5 & 0.5 & 0.5 \\
Salt & 0.5 & 0.5 & 0.5 & 0.5 \\
Vitamin C(mg/kg) & 92 & 0 & 23 & 46 \\
Palm Kernel cake (P.K.C) & 5 & 5 & 5 & 5 \\
\hline \hline
\end{tabular}

Table 2: Liver Ascorbic Acid Concentration of Analyzed Fish Samples

\begin{tabular}{lcccc}
\hline Sample No. & $\begin{array}{c}\text { Pond 1 } \\
\text { (92mg/kg AA) }\end{array}$ & $\begin{array}{c}\text { Pond 2 } \\
\text { (0mg/kg AA) }\end{array}$ & $\begin{array}{c}\text { Pond 3 } \\
(\mathbf{2 3 m g / k g ~ A A )}\end{array}$ & $\begin{array}{c}\text { Pond 4 } \\
(\mathbf{4 6 m g / k g ~ A A )}\end{array}$ \\
\hline $\mathbf{1}$ & $45.68 \%$ & $20.84 \%$ & $32.93 \%$ & $40.28 \%$ \\
$\mathbf{2}$ & $48.24 \%$ & $22.31 \%$ & $32.87 \%$ & $42.87 \%$ \\
$\mathbf{3}$ & $46.32 \%$ & $20.96 \%$ & $33.12 \%$ & $39.80 \%$ \\
\hline \hline
\end{tabular}

Table 3: The Proximate Composition of Experimental Diets

\begin{tabular}{|c|c|c|c|c|c|}
\hline \multicolumn{6}{|c|}{$\begin{array}{l}\text { \% composition of Crude Nutrients } \\
\text { (Replicates) }\end{array}$} \\
\hline Nutrients & 1 & 2 & 3 & 4 & Mean \\
\hline *Crude Protein & $36.80 \%$ & $37.20 \%$ & 38.50 & $37.10 \%$ & 37.4 \\
\hline Crude fat & $3.60 \%$ & $2.01 \%$ & $3.28 \%$ & $2.86 \%$ & 2.94 \\
\hline Crude fibre & $6.80 \%$ & $6.20 \%$ & $5.06 \%$ & $8.04 \%$ & 6.53 \\
\hline Moisture & $0.85 \%$ & $0.65 \%$ & $0.55 \%$ & $0.82 \%$ & 0.72 \\
\hline Ash & $7.04 \%$ & $7.01 \%$ & $5.42 \%$ & $8.82 \%$ & 7.07 \\
\hline Carbohydrate & $44.91 \%$ & $46.93 \%$ & $47.19 \%$ & $42.36 \%$ & 45.34 \\
\hline
\end{tabular}

* Percentage tabular crude protein for the experimental locally formulated feed. But calculated crude protein was $40 \%$.

Table 4: Growth Performance and Nutrient Utilization

\begin{tabular}{lcccc}
\hline Parameters & $\begin{array}{c}\text { Pond 1 } \\
\text { (92mg/kgA) }\end{array}$ & $\begin{array}{c}\text { Pond 2 } \\
\text { (0mg/kg AA) }\end{array}$ & $\begin{array}{c}\text { Pond 3 } \\
\text { (23mg/kgAA) }\end{array}$ & $\begin{array}{c}\text { Pond 4 } \\
\text { (46mg/kgAA) }\end{array}$ \\
\hline Mortality & 2 & 14 & 5 & 6 \\
\% mortality & 1.33 & 10.77 & 4.67 & 3.28 \\
Survival & 148 & 116 & 102 & 177 \\
Survival (\%) & 98.7 & 89.2 & 95.3 & 96.7 \\
Total final weight of fish(g) & 130,240 & 60,900 & 26,000 & 109,740 \\
\multicolumn{1}{c}{ experimental } & feed & & & \\
Total & 154,800 & 56,600 & 29,127 & 98,750 \\
consumed(g) & & & & 3.0 \\
Initial mean weight of fish(g) & & & & 620 \\
Final mean weight(g) & 5.85 & 2.14 & 2.14 & 617 \\
Mean weight gain(g) & 880 & 530 & 260 & 3.5 \\
Feed intake (g) & 874.15 & 527.86 & 257.74 & $36,932.5$ \\
Protein intake(g) & 6.5 & 3.0 & 2.7 & 4.75 \\
SGR (\%/day) & $57,895.2$ & $21,168.4$ & $10,893.5$ & 0.9 \\
Feed conversion ratio & 4.5 & 4.9 & 4.3 & 2.9 \\
Protein efficiency ratio & 1.2 & 0.9 & 1.1 & 2.5 \\
\hline
\end{tabular}

Fish fed with $92 \mathrm{mg} / \mathrm{kg}$ AA supplementation showed significantly higher weight gain than those fed with $0 \mathrm{mg} / \mathrm{kg}, \quad 23 \mathrm{mg} / \mathrm{kg}$ and $46 \mathrm{mg} / \mathrm{kg}$ respectively. However, the group that received $0 \mathrm{mg} / \mathrm{kg}$ AA had a higher SGR (4.75\%/day) than the other groups fed diets containing higher amounts of AA generally, and particularly higher mean weight gain than those fed with $23 \mathrm{mg} / \mathrm{kg}$ AA supplemented diet. This probably could be attributed to their smaller initial mean weights and genetic factors. 
Length-Weight Relationship: For the four ponds, weight regressed positively on the length. The regression coefficients "b" values: $2.785,2.4398$ and 2.4972 .398 and 2.595 for the four respectively indicated a highly significant regression of weight on length $(\mathrm{P}<0.05)$. The regression coefficient " $\mathrm{b}$ " value obtained for each experimental pond was less than 3 , thus indicating an allometric growth pattern for the fish in each of the experimental ponds. The correlation values for each pond specimens also indicate a high correlation between increase in length of fish and weight gained.

Physical Observation of Fish Samples: The results of physical observation of the entire fish samples are presented in table 5. None of the samples fed with diets containing $92 \mathrm{mg} / \mathrm{kg}$ AA (pond 1) and $46 \mathrm{mg} / \mathrm{kg}$ AA (pond 4) showed any visible signs of deficiency which indicate a healthy fish. However, $93.1 \%$ of the total population of samples fed with diets without AA supplementation (pond 2) showed deficiency signs, of which $1.72 \%$ of the population were observed with nodular swells on the neck region; $91.38 \%$ were observed to have both head lesions and pronounced sutures and $15.52 \%$ had eroded skin. Similarly, $82.35 \%$ of samples fed with $23 \mathrm{mg} / \mathrm{kg}$ AA diets (pond 3 ) were observed to have deficiency signs of both head lesion and pronounced sutures, while $3.39 \%$ had skin erosion. Fish samples in ponds 2 and 3 (fed with $0 \mathrm{mg} / \mathrm{kg}$ AA and $23 \mathrm{mg} / \mathrm{kg}$ AA respectively) suffered similar deficiency signs such as nodule-like swells on neck, skin and head lesions and pronounced sutures.

In the present study, survival of $C$. gariepinus improved with increasing supplementation of dietary vitamin $\mathrm{C}$ and the highest mean weight gain was observed in the group that received $92 \mathrm{mg} / \mathrm{kg}$ vitamin $\mathrm{C}$ in their diet. The essence of the sorting of similar sizes into a group was for the elimination of effects of genetic factors on growth outside the single influence of vitamin $\mathrm{C}$ supplements in the diets, in accord with the suggestion of Ndome et al. (2011) and Martins et al. (2005). The result of this procedure was noticed in the mean weight gain of the group fed $0 \mathrm{mg} / \mathrm{kg}$ AA supplemented diet being significantly $(\mathrm{P}<0.02)$ higher than that of the group which received $23 \mathrm{mg} / \mathrm{kg}$ AA supplemented diet; though mortality was higher as vitamin C supplementation decreased in the diets. In addition, both groups fed with less enthusiasm than the group that received 46 and $92 \mathrm{mg} / \mathrm{kg}$ AA supplementation. Fish during the experiment generally had increased growth except in the $25^{\text {th }}$ and $26^{\text {th }}$ week of the sampling where stagnation was observed in pond 2 (fed $0 \mathrm{mg} / \mathrm{kg} \mathrm{AA}$ diet). This indicates that AA has a specific effect on growth, as also reported by Ibiyo et al. (2007), Adewolu et al. (2009); Eya and Mabenka (1990). This is also reflected in the significantly $(\mathrm{P}<0.001)$ lower liver AA (Table 2) of this group than the other groups which received AA supplementation. 
Table 5: Physical Observation of Fish Samples

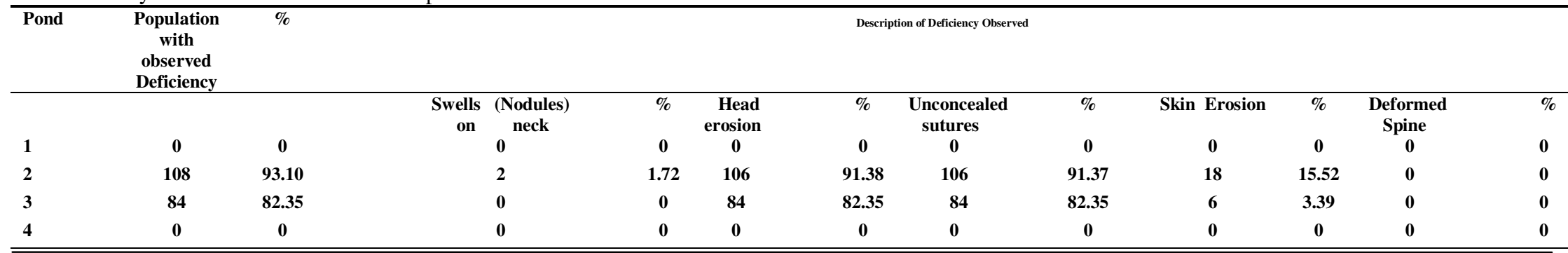


The smaller size of fish in pond 3 probably could be attributed to internal or genetic factors (Martins et al., 2005) or a combination of these and the lower AA supplementation in their diet. The results observed in these two groups is unlike that earlier reported by some previous authors; who reported a generally lower growth in only the groups given diets without AA supplementation (Ibiyo et al., 2007; Adewolu and Aro, 2009). The reduced growth towards the $26^{\text {th }}$ week of the experiment in groups given $0 \mathrm{mg} / \mathrm{kg}$ AA diets may also support the reason for the poor performance of catfish progeny from a brood fish fed diets with low vitamin $\mathrm{C}$ supplement (Chatakondi et al., 2010).

Ndome et al. (2011) disagreed with Fasakin et al. (2003) as fishes fed with artificial diet (Multifeed) performed better than those fed with natural feed only. This argument is similar to the views of Shoko et al. (2014) and many fish farmers that locally produced fish feeds (which normally sink) gives the same or even better results than the imported floating types, as catfish sometimes exhibit behavioural adaptive changes. However, this study prove the regression coefficient (b) value obtained for the four ponds were less than 3 thus indicating an allometric growth (Edema et al., 2005) such that fish did not become quickly rotund as they grew in length; though pond 1 was closer to having increased roundness as length increased than the other three ponds. It appeared that imported floating feed was more attractive to the fish and they feed with more enthusiasm than the locally produced feeds which had less attractant. However, catfish could sustain a fair health in adult stage without supplemental dietary vitamin $\mathrm{C}$ if minimum amounts of vitamin $\mathrm{C}$ are fed to them at their early stage of development (Ibiyo et al., 2007; Edwin and $\mathrm{Li}$, 1996) in their diets. Deficiency of supplemental vitamin $\mathrm{C}$ in Catfish diets could increase the risk of diseases and low aesthetic value of the fish due to skin and head lesions (or erosion).

Conclusion: A minimum of $92 \mathrm{mg} / \mathrm{kg}$ AA should be included in locally formulated catfish feeds. More stable forms of AA (obtained by combination with other elements such as phosphorus and calcium) may be preferably used in the feed manufacture, other than the pure forms while are heat labile in nature. Standardized formulation and proper feed management is important in large commercial catfish farms to ensure healthiness and good growth of the fish.

\section{REFERENCES}

Adewolu, MA.; Aro, OO (2009). Growth, Feed Utilization and Haematology of Clarias gariepinus (Burchell, 1822) Fingerlings Fed Diets Containing Different Levels of Vitamin C.
American Journal of Applied Sciences, 6(9):1675-1681.

AOAC (2000). Association of Official Analytical Chemist. Official methods of Analysis 17th ed. Washington D.C.

Behera, PC (2015). Major non-infectious diseases in catfishes and their preventive measures. 2pp. http://en.engormix.com/MAaquaculture/articles/major-non-infectiousdiseases-t3568/p0.htm.

Boyd, CE (1990). Water Quality in Ponds for Aquaculture. 2nd Edn., Alabama Agricultural Experiment Station, Auburn University, Auburn, AL., USA., 482pp.

Chatakodi, N L; Peterson, BC; Oberle, D; Bosworth, BG (2010). Maternal transfer of vitamin $C$ in channel catfish (Ictahirus punctatus.): Effects, reproduction and progeny performance. Proceedings of International Congress on Biology of Fishes. 9:44-45.

Edema, CU; Ogbeibu, AE; Imoagene, HU (2005). Allometric indices of Chromidotilapia guentheri (Sauvage, 1882) , Tilapia mariae (Boulenger, 1899) and Tilapia zillii (Gervais, 1848) of the Osse river, Southern Nigeria. Africa Scientist Vol.6, No.3.

Edwin, HR; Li, MH (1996). A practical guide to nutrition, feeds, and feeding of Catfish. Mississippi Agricultural and Forestry Experiment station, bulletin 1041- march 1996. http:1lmsucare.com/pubs/bulletins/b1044.htm

Eya. JC; Mgbenka, BO (1990). Ascorbic acid (vitamin C) requirement of African Catfish, Clarias gariepinus (Tengelo 1984). J. Aquat. Sci., 5:65-75.

http://www.fao.org/agris/search/display.do?f=./1994/ v2011/NG9400058.xml;NG94000058.xml;NG94 00058

Gbadamosi, OK; Fasakin, EA; Adebayo, O T (2013). Clinical changes observed in Clarias gariepinus (Burchell 1822) fed varying levels of ascorbic acid supplementation. Afr. J. Agric. Res. Vol. 8(30), pp. 4122-4127. doi: 10.5897/AJAR09.462. http://www.academicjournals.org/AJAR

Ibiyo, LMO; Atteh, JO; Omotosho, JS; Madu, CT (2007). Vitamin C (Ascorbic acid) requirements of Heterobranchus longifilis fingerlings. Afri. J. Biotech., 6: 1559-1567. 
http:/www.bioline.org.br/abstract?id=jb07273\&l ang=en

Idodo-Umeh, G (2003). Freshwater fishes of Nigeria (Taxonomy, Ecological Notes, Diets and Utilization). Idodo-Umeh Publishers Ltd., Benin. $243 p p$.

Martins, CIM; Schrama, J W; Verreth, JAJ (2005). Inherent variation in growth efficiency of African catfish Clarias gariepinus (Burchell, 1822) juveniles. Aquaculture Research, 36: 868875. doi:10.1111/j.1365-2109.2005.01295.x

Ndome, CB; Udo, IU; Nkereuwen, SN (2011). Effect of Organic fertilizer and Formulated Feed on the Growth Performance and Condition Factor of Clarias gariepinus and Heterobranchus longifilis Hybrid. Journal of Agricultural Research, 6: 632 - 642. http:// scialert.net/abstract/? doi=ijar.2011.632.642.
Ogbeibu, AE (2005). Biostatistics: A practical Approach to research and data handling. Mindex Publishing Company Limited, Benin. 264p.

Panase, P; Mengumphan, K (2015). Growth Performance, Length-Weight Relationship and Condition Factor of Backcross and Reciprocal Hybrid Catfish Reared in Net Cages. International Journal of Zoological Research, 11: $57-64$.

http://scialert.net/abstract/?doi=ijzr.2015.57.64

Shoko, AP; Ndikumana, J; Zziwa, E; Musiba, MJ; Ngupula, GW; Kashindye, BB; Elison, M; Katunzi, EFB (2014). Performance of locally formulated feeds for rearing of African Catfish in Tanzania. African Crop Science Journal, Vol. 22, Issue Supplements 4, pp. 979 - 986.

Yamamoto, Y; Sato, M; Ikeda, S (1985). Existence of L-gulonolactone oxidase in some telecosts. Bull. Jpn. Soc. Sci. Fish 44:775-779. 